\title{
Impact of Front Line Demonstrations on the Yield and Economics of Black Gram in Rabi Rice Fallows in Krishna District of Andhra Pradesh
}

\author{
Srilatha, P. * and Srilatha Vani, Ch.
}

Acharya N.G. Ranga Agricultural University, Guntur, Andhra Pradesh, India

"Corresponding author: srilathajeyabal@gmail.com (ORCID ID: 0000-0001-6624-7426)

Paper No. 855

Received: 14-04-2020

Revised: $12-07-2020$

Accepted: 26-08-2020

\begin{abstract}
In the year 2016-17 Cluster front line demonstrations (CFLDs) were organised in $40 \mathrm{Ha}$, in 2017-18 in 50 $\mathrm{Ha}$ and in 2018-19 it was done in 50 hectares. All the critical inputs were provided to the farmers free of cost. In Andhra Pradesh, the average yield of black gram was 8.0 qt./Ha and average yield of Krishna district was $10.3 \mathrm{qt} / \mathrm{Ha}$, a potential pulse producing district in the state and the potential yield is 15 $\mathrm{qt} /$ Ha. Extension activities viz., training programmes, method demonstrations, field visits and group discussion were organised to create awareness on the latest technologies and skill component involved. The average data for all three years indicate that in the demonstrated plots the average yield was 14.3 $\mathrm{qt} /$ ha compared to $12.8 \mathrm{qt} / \mathrm{h}$ in the farmers practice fields. The cost of cultivation was also reduced in the demonstrated plots ( $₹ 23110.00$ per hectare) compared to farmers practice pots ( $₹ 28900$ ) indicating a reduction, resulted in improving the net income of the farmers in the demonstration plots. There is a increase in the net income in demonstrated plots to the tune of ₹ 11965.00 per hectare and the cost benefit ratio was also greatly improved from 2 to 3 in the demonstrated plots.
\end{abstract}

\section{Highlights}

( The average yield data recorded indicate significant improvement in the yield (23.11\% increase) obtained and the gap in the yield is considerably reduced

- Along with reduction in yield gap reduction in cost of cultivation is also observed in the demonstration plots to the tune of ₹ 5790 per hectare.

Keywords: Front line demonstrations, cost of cultivation, farmers practice, yield and economics

A variety of pulses is grown in India under a wide range of agro-climatic conditions. It is well known fact that pulses are inseparable ingredients of vegetarian diet and one of 'the cheapest sources of dietary protein for Indians. Presently, India is producing about 18.4 million ton of pulses from an area of about 24 million hectare with $786 \mathrm{~kg} /$ ha productivity and contributing about 21 per cent into global production. However, about 2 - 3 million ton of pulses are imported annually to meet the domestic consumption requirement. Thus, there is need to increase production and productivity of pulses in the country by more intensive interventions.
Urad bean (Blackgram) crop is also gaining momentum since 2015-16 and there has been phenomenal increase in its coverage. During 201718 , the crop was cultivated over an area of $>50$ Lha. The success of this crop was released with a harvest of about $14 \mathrm{Lt}$ at an ever highest yield levels of $352 \mathrm{~kg} / \mathrm{ha}$. More than 90 per cent of urad bean production comes from 08 states of Madhya Pradesh, Rajasthan, Uttar Pradesh, Andhra Pradesh,

How to cite this article: Srilatha, P. and Srilatha V. Ch. (2020). Impact of Front Line Demonstrations on the Yield and Economics of Black Gram in Rabi Rice Fallows in Krishna District of Andhra Pradesh. IJAEB, 13(3): 345-348.

Source of Support: None; Conflict of Interest: None 
Tamil Nadu, Maharashtra, Karnataka and Orissa (Annonymous, 2011).

To meet the domestic demand of pulse requirement and ensure self-sufficiency in pulses, a sustainable production and productivity approach has to be maintained by deploying multi-pronged short-term and long-term strategies.

Major developmental interventions in pulses were initiated with the inclusion of pulses (NPDP) in the TMOP during VIIIth plan (1992-97). NPDP was followed by ISOPOM since 2007-08, the NFSM-Pulses is a major scheme and today is under implementation in 29 states in 638 districts of the country during 2017-18. The NFSM aimed at increasing production of rice, wheat and pulses through area expansion and productivity enhancement; restoring soil fertility and productivity; creating employment opportunities; and enhancing farm level economy to restore confidence of farmers of targeted districts. The basic strategies were implementation of interventions in a mission mode through active engagement of all the stake holders at various levels. These interventions include promotion and extension of improved technologies i.e., Seed, Integrated Nutrient Management (micronutrient, soil amendments), IPM and resource conservation technologies (RCTs) along with capacity building of farmers (Rakshit et al. 2018). Flow of fund closely monitored to ensure that intervention reach the target beneficiaries on time, Interventions proposed were integrated with the district plan and target for each identified district was fixed. Constant monitoring and concurrent evaluation were done for assessing the impact of the interventions for a result oriented approach by the implementing agencies.
During the 3 years of programme implementation i.e. 2016-17 to 2018-19 there has been substantial growth in production and productivity of pulses with the support and extension work taken-up by both central and state governments. These demonstrations are conducted under the close supervision of scientists of Krishi Vigyan Kendras, SAUs and their Regional Research Stations. The results demonstrate the effectiveness of policy interventions. On this background the present study was undertaken with the following specific objectives namely to find out the level of blackgram productivity among beneficiary and non beneficicary farmers, to identify the adoption scenario of recommended blackgram technology among beneficicary farmers.

\section{METHODOLOGY}

Paddy fallow blackgram is practiced in Krishna district and its soil is best suited for blackgram cultivation. This district was selected purposively from Andhra Pradesh. Krishi Vigyan Kendra, Ghantasala, Krishna district has conducted Cluster frontline demonstrations in Rabi seasons in the farmer's fields during 2016-17 to 2018-19 by demonstrating INM and IPM practices. Preliminary information regarding clusters was collected through Participatory Rural Appraisal (PRA) techniques. Five CFLD clusters under coverage area of NFSM were selected. The awareness programme (pre season training) was organized for selection of farmer's. A group of cooperative farmers were identified based on their participation and feedback received during the preliminary survey and interactive meeting. All 130 demonstrations in 325 ha area were

Table 1: Area, Production and Productivity of Blackgram in Major States

\begin{tabular}{|c|c|c|c|c|c|c|}
\hline Sl. No. & Particulars & Area (lakh ha) & \% Share & Production (lakh $\mathrm{t}$ ) & \% Share & Productivity (kg ha-1) \\
\hline 1 & Andhra Pradesh & 5.03 & 16.23 & 2.59 & 18.50 & 514.91 \\
\hline 2 & Karnataka & 1.26 & 4.06 & 0.64 & 4.57 & 507.94 \\
\hline 3 & Madhya Pradesh & 4.72 & 15.23 & 1.66 & 11.86 & 351.69 \\
\hline 4 & Maharashtra & 5.75 & 18.55 & 3.27 & 23.36 & 568.70 \\
\hline 5 & Uttar Pradesh & 3.91 & 12.61 & 1.72 & 12.29 & 439.90 \\
\hline 6 & Rajasthan & 1.45 & 4.68 & 0.60 & 4.29 & 413.79 \\
\hline 7 & Tamil Nadu & 3.41 & 11.00 & 1.21 & 8.64 & 354.84 \\
\hline \multirow[t]{3}{*}{8} & Orissa & 1.50 & 4.84 & 0.42 & 3.00 & 280.00 \\
\hline & Sub-total & 27.03 & 87.19 & 12.11 & 86.50 & 448.02 \\
\hline & Total & 31.00 & & 14.00 & & 451.61 \\
\hline
\end{tabular}


conducted with the active participation of farmers to demonstrate the improved technologies of pulses production.

For the selected farmers, critical inputs for the technologies to be demonstrated were distributed. Seasonal long training programmes were organised along with distribution of literature followed by regular field visits. Monitoring of pest and diseases infestation in the cluster villages and accordingly regular advisory services was given by the KVK scientist. Finally field day was conducted involving cluster demonstration farmers, other farmers in and around the village, Scientists from University and ATARI, officials from Department of Agriculture and local extension functionaries to demonstrate the superiority of the technology in Blackgram crop. From the selected cluster villages two lists of beneficiary and non - beneficiary farmers were prepared. The information pertaining to the objectives were collected through well structured schedules from 60 beneficiary farmers of NFSM.

Pulse and 60 non-beneficiary farmers from the selected five villages. Thus, the total sample size was 120 blackgram growers. To know the response of blackgram farmers on adoption of recommended technology adoption scenario was recorded and presented under nine components. For analysis statistical tests i.e. frequency, percentage and mean were used for analyzing and interpreting the data.

\section{RESULTS AND DISCUSSION}

The average yield of blackgram in the demonstrated and farmers fields is presented in table 2. The results revealed that average grain yield of Black gram under cluster frontline demonstrations is $14.3 \mathrm{q} /$ ha with average cost of cultivation of
₹ 23110 as compared $12.8 \mathrm{q} /$ ha recorded in farmer's practice with average cost of cultivation of ₹ 28900 respectively. These results in accordance with the findings of Jayalakshmi Mitnala et al. (2018). The observed decrease in cost of cultivation in demonstration plots is due to motivation gained by the farmers through different capacity building programmes organised by KVK, Ghantasala to follow the recommended cultivation practices.

The economic analysis results revealed that the black gram recorded higher total average return from recommended practice (CFLD's) were ₹ 69343.00/ ha as compared to farmers practice ₹ 63168.00/ ha respectively. The net returns were ₹ 46233.00/ha in recommended practice in comparison to ₹ 34268.00/ha respectively in farmer's practice. The benefit cost ratio also recorded higher in recommended practice with an average of 3.00 as compared to 2.18 in farmer's practice These results in accordance with the findings of Gurumukhi and Mishra (2003), Dhaka et al. (2010) and Singh et al. (2018).

\section{Adoption scenario of recommended blackgram technology among beneficiary farmers}

Schedule with nine components of the recommended blackgram technological practices i.e. on Seed treatment, Use of pre emergence herbicide, Use of post emergence herbicide, Spraying of Neem oil, Application of Multi K, Irrigation before flowering, Control measures against sucking pests, Control measures against Spodoptera, Use of Yellow / blue sticky traps at appropriate time in field was prepared to know the responses of beneficiary farmers about adoption and non adoption with causes. The data related to the above aspects were presented in frequency and percentage.

Table 2: Yield and Economics of Blackgram

\begin{tabular}{lllllllllll}
\hline & \multicolumn{3}{c}{ Yield (q/ha.) } & \multicolumn{3}{c}{ Farmers Plot } \\
\cline { 2 - 10 } Year & $\begin{array}{l}\text { Demo. } \\
\text { plot }\end{array}$ & $\begin{array}{l}\text { Farmers } \\
\text { plot }\end{array}$ & $\begin{array}{l}\text { Cost of } \\
\text { cultivation } \\
(₹ / h a .)\end{array}$ & $\begin{array}{l}\text { Gross } \\
\text { income } \\
\text { (₹/ha.) }\end{array}$ & $\begin{array}{l}\text { Net } \\
\text { income } \\
\text { (₹/ha.) }\end{array}$ & $\begin{array}{l}\text { B:C ratio } \\
\text { (₹/ha.) }\end{array}$ & $\begin{array}{l}\text { Cost of } \\
\text { cultivation } \\
\text { (₹/ha.) }\end{array}$ & $\begin{array}{l}\text { Gross } \\
\text { income (₹/ } \\
\text { ha.) }\end{array}$ & $\begin{array}{l}\text { Net } \\
\text { income (₹/ } \\
\text { ha.) }\end{array}$ & $\begin{array}{l}\text { B:C ratio } \\
\text { (₹/ha.) }\end{array}$ \\
\hline $2016-17$ & 15.0 & 13.5 & 29250 & 63500 & 34250 & 2.17 & 23190 & 69933 & 46743 & 3.01 \\
$2017-18$ & 14.5 & 13.0 & 28350 & 62750 & 34400 & 2.21 & 22650 & 69105 & 46455 & 3.05 \\
$2018-19$ & 13.5 & 12.0 & 29100 & 63255 & 34155 & 2.17 & 23490 & 68990 & 45500 & 2.93 \\
Average & 14.3 & 12.8 & 28900 & 63168 & 34268 & 2.18 & 23110 & 69343 & 46233 & 3.00 \\
\hline
\end{tabular}


Response under adoption side showed that 100 per cent beneficiary farmers do adopt application of Multi $\mathrm{K}$ in blackgram production, 95 per cent beneficiary farmers adopted control measures against spodoptera, irrigation before flowering followed by other recommended blackgram technologies. Extent of adoption by the beneficiary farmers was observed to be high when compared to non beneficiary farmers. As per table no.4.0 non beneficiary farmers showed poor level of adoption of IPM practices like use of yellow / blue sticky traps at appropriate time in filed (20\%), spraying of neem oil (31.6\%) and seed treatment (56.6\%).

Table 3: Adoption scenario of recommended Black gram technology among beneficiary farmers $(\mathrm{N}=60)$

\begin{tabular}{lll}
\hline Recommended Technology & No. & \% \\
\hline Seed treatment & 50 & 83 \\
Use of pre emergence herbicide & 44 & 73 \\
Use of post emergence herbicide & 52 & 86 \\
Spraying of Neem oil & 55 & 91 \\
Application of Multi K & 60 & 100 \\
Irrigation before flowering & 57 & 95 \\
Control measures against sucking & 56 & 93 \\
pests & & \\
Control measures against Spodoptera & 57 & 95 \\
Use of Yellow / blue sticky traps at & 52 & 86 \\
appropriate time in field & & \\
\hline
\end{tabular}

Table 4: Adoption scenario of recommended Black gram technology among non beneficiary farmers $(\mathrm{N}$ $=60$ )

\begin{tabular}{lll}
\hline Recommended Technology & No. & \% \\
\hline Seed treatment & 34 & 56.6 \\
Use of pre emergence herbicide & 41 & 68.3 \\
Use of post emergence herbicide & 50 & 83.3 \\
Spraying of Neem oil & 19 & 31.6 \\
Application of Multi K & 44 & 73.3 \\
Irrigation before flowering & 52 & 86.6 \\
Control measures against sucking pests & 44 & 73.3 \\
Control measures against Spodoptura & 52 & 86.6 \\
Use of Yellow / blue sticky traps at & 12 & 20.0 \\
appropriate time in field & & \\
\hline
\end{tabular}

\section{CONCLUSION}

On the basis of the findings of the study, it can be concluded that productivity level of blackgram was higher in demonstration units than farmers practice. This impact was the combination of technological package (capacity building programmes and inputs provided by NFSM-P team). The adoption scenario indicates that poor blackgram productivity was the result of either poor knowledge or faulty/ non-adoption of recommended technology or combination of both. Extent of adoption by the beneficiary farmers was observed to be high when compared to non beneficiary farmers. However beneficiary farmers are good in adopting the application of Multi $\mathrm{K}$ in blackgram production, control measures against spodoptera, irrigation before flowering followed by other recommended blackgram technologies. Non beneficiary farmers showed poor level of adoption of IPM practices like use of yellow / blue sticky traps at appropriate time in filed (20\%), spraying of neem oil (31.6\%) and seed treatment (56.6\%) this may be due to poor exposure of capacity building programmes.

\section{REFERENCES}

Annonymous. 2011 Area, Production and Productivity of Major Pulses, Agropedia, pp. 5.

Dhaka, B.L, Meena, B.S. and Suwalka, R.L. 2010. Popularization of improved maize technology through frontline demonstration in South-eastern Rajasthan. Journal of Agricultural Sciences, 1: 39-42.

Gurumukhi, D.R. and Mishra, S. 2003. Sorghum front line demonstration - A success story. Agriculture Extension Review, 15(4): 22-23.

Jayalakshmi Mitnala, Prasad Babu, G., Ragavendra Chowdary, K., Vijayabhinandana, B. and Subba Rao, M. 2018. Impact of Cluster Frontline Demonstrations (CFLDs) on Pulse Production Productivity, Profitability and Transfer of Technologies in Kurnool District of Andhra Pradesh, India, International Journal of Current Microbiology and Applied Sciences, 7(12).

Rakshit, A., Sarkar, B. and Abhilash, P. 2018. Soil amendments for sustainability: challenges and perspectives. CRC Press, Boca Roton, FL, 13:978-1-3510-2700-7, pp. 428.

Singh, S.P., Paikra, K.K. and Chanchala Rani Patel. 2018. Performance of cluster frontline demonstration on productivity and profitability of Blackgram (Vigna mungo) in Raigarh District of Chhattisgarh, India. Int. J. Curr. Microbiol. App. Sci., 7(06): 1325-1330. 